\title{
Simulation of inorganic nitrogen dynamics and shrimp survival in an intensive shrimp culture system
}

\author{
R A Montoya ${ }^{1}$, A L Lawrence ${ }^{2}$, W E Grant ${ }^{1}$ \& M Velasco ${ }^{3}$ \\ ${ }^{1}$ Department of Wildlife and Fisheries Sciences, Texas A \& M University, College Station, TX 77843-2258, USA \\ ${ }^{2}$ Shrimp Mariculture Research Project, Texas A \& M University System, 1300 Port St., Port Aransas, TX 78373, USA \\ ${ }^{3}$ Empacadora Nacional C.A., PO Box 09-01-4344, Guayaquil, Ecuador
}

Correspondence: W. E. Grant, Department of Wildlife and Fisheries Sciences, Texas A \& M University, College Station, TX 77843-2258, USA. E-mail: wegrant@tamu.edu

\begin{abstract}
Nitrogenous wastes are major concerns in shrimp production and as a component of total farm wastes that impact the aquatic environment. This study describes a simulation model of the role of heterotrophic and nitrifying bacteria on nitrogen dynamics in intensive Litopenaeus vannamei (Boone) culture systems using different feeds and feeding strategies. The model represents: (i) use and remineralization by heterotrophic bacteria of nitrogen wastes and ammonia excreted by shrimp; and (ii) nitrification. The model was quantified using published and unpublished information. The model is multivariate, deterministic and uses a compartment model structure based on difference equations. Evaluation of the model consisted of simulating two indoor and one outdoor experiment that examined the effects of different feeds and feeding levels on nitrogen dynamics. In summary, the model is capable of qualitatively following inorganic nitrogen dynamics. Simulations investigating the effect of heterotrophic remineralization on total inorganic nitrogen suggested that this process may contribute up to $97 \%$ of the inorganic nitrogen in the system. This indicates that strategies to increase production, such as increases in feed protein levels or feeding rates, should be carefully evaluated before they are implemented. Future studies need to address bacterial community role in these systems and inorganic nitrogen toxicity mechanisms.
\end{abstract}

Keywords: modelling, nitrogen dynamics, simulation, shrimp culture

\section{Introduction}

Static wild catches of shrimp, desire for foreign revenue in tropical and subtropical developing countries, development of new technologies and high return on investment have contributed to the rapid growth of shrimp culture worldwide (Phillips, Lin \& Beveridge 1993). The tendency of the shrimp industry to increase production by increasing stocking density requires an increase in feed input which is the primary cause of water quality problems (Goddard 1996). Currently, water quality problems are solved by water exchange, which represents a waste of water resources and creates an effluent discharge problem (Wang 1990). Besides dissolved oxygen, nitrogenous compounds, for example ammonia $\left(\mathrm{NH}_{3}\right)$ and nitrite $\left(\mathrm{NO}_{2}^{-}\right)$are major concerns owing to their toxicity to shrimp (Wickins 1976). The main sources of ammonia in culture systems are shrimp excretion and decomposition of detritus (particulate and dissolved non-living organic matter). In aquaculture systems, uneaten feed pellets, disintegrated feed particles and animal excreta form part of the detritus pool which, when decomposed by heterotrophic bacteria, may produce ammonia (Goldman, Caron, Andersen \& Dennett 1985; Goldman, Caron \& Dennett 1987; Moriarty 1997). In water, a dynamic equilibrium between the toxic ammonia form $\left(\mathrm{NH}_{3}\right)$ and the non-toxic ammonium ion $\left(\mathrm{NH}_{4}^{+}\right)$is established, the sum of which is known as total ammonia nitrogen (TAN). This equilibrium is dependent on temperature and $\mathrm{pH}$. At a normal seawater $\mathrm{pH}$ value of 8.0, approximately $95 \%$ of the TAN is in the form of the ammonium ion (Vymazal 1994). TAN may be used as a 
nitrogen source by heterotrophic bacteria, phytoplankton, algae and plants (Wheeler \& Kirchman 1986; Fuhrman, Horrigan \& Capone 1988; Vymazal 1994), and as an energy source by nitrifying bacteria (Vymazal 1994). Nitrifying bacteria oxidize TAN first to nitrite and then nitrite is oxidized to nitrate $\left(\mathrm{NO}_{3}{ }^{-}\right)$, which is not toxic to shrimp. It would be very valuable to predict the dynamics of nitrogen forms in shrimp culture systems to avoid negative effects on shrimp growth and survival. However, the complex interactions among feed input and its wastes, shrimp metabolism and bacteria use and remineralization of nitrogen compounds, makes prediction of nitrogen dynamics very difficult.

Montoya, Lawrence, Grant \& Velasco (1999) developed a model to examine the effect of feed stability, duration of feeding stimulant effect, dietary protein level, protein digestibility, feeding frequency, amount of feed per feeding, time of feeding, and feeding rate on shrimp growth and production of nitrogen wastes for an intensive, low-water-exchange culture system receiving dry feeds without natural productivity, except bacteria. In this paper, we focus on the development of a simulation model to examine the effect of heterotrophic and nitrifying bacterial use and remineralization of nitrogen wastes on TAN, $\mathrm{NO}_{2}{ }^{-} \mathrm{N}$ and $\mathrm{NO}_{3}{ }^{-} \mathrm{N}$ concentrations in the water and their effects on shrimp survival. After examining the correspondence between model predictions and experimental results, the model is used to examine the contribution of heterotrophic bacteria remineralization on total inorganic nitrogen concentration in the water under different feeding regimes.

\section{Model overview}

This model includes two submodels representing bacterially mediated processes (Fig. 1) and white shrimp, Litopenaeus vannamei (Boone) survival (Fig. 2) under optimum enviromental conditions for this species. These environmental conditions are represented as constant: temperature range from $28^{\circ} \mathrm{C}$ to $30^{\circ} \mathrm{C}$; $\mathrm{pH}$ range from 7.8 to 8.0 ; and oxygen levels above 5.0 p.p.m. The bacteria submodel represents three processes: (i) heterotrophic bacterial utilization of inorganic and organic nitrogen; (ii) heterotrophic bacterial remineralization of $\mathrm{NH}_{4}{ }^{+}-\mathrm{N}$; and (iii) nitrification. The survival submodel represents mortality as a result of toxic levels of
$\mathrm{NH}_{3}-\mathrm{N}$ and/or $\mathrm{NO}_{2}{ }^{-} \mathrm{N}$ and as a result of site-specific conditions. The model is formulated as a deterministic compartment model based on difference equations programmed using STELLA ${ }^{\circledR}$ Research vs. 5.1 ${ }^{\complement}$ High Performance Systems (1998), and runs on a personal computer using a 1-h time-step; this means that all values are updated every hour. The initial values for all state variables are defined by the user at the beginning of each simulation.

\section{Bacteria submodel}

More specifically, the bacteria submodel (Fig. 1) represents nitrogen uptake by heterotrophic bacteria (NHB) from organic forms including nitrogen in uneaten whole feed (UFN), feed disintegrated in particles (PFN) and faeces (NFE); and from inorganic sources including $\mathrm{NH}_{4}{ }^{+}-\mathrm{N}$. This submodel also represents bacteria remineralization of $\mathrm{NH}_{4}{ }^{+}-\mathrm{N}$. Nitrification is included as the flow of $\mathrm{NH}_{4}{ }^{+}-\mathrm{N}$ to $\mathrm{NO}_{2}{ }^{-}-\mathrm{N}$ and to EMBED $\mathrm{NO}_{3}{ }^{-} \mathrm{N}$. The heterotrophic bacterial population (HBP), the Nitrosomonas sp. population (NSP) and the Nitrobacter sp. population (NBP) are represented as independent state variables.

Marine shrimp are ammoniotelic and $\mathrm{NH}_{3}-\mathrm{N}$ constitutes between $60 \%$ and $100 \%$ of the nitrogenous catabolites (Rosas, Sanchez, Diaz, Soto, Gaxiola \& Brito 1996). Amino acids in excess of those needed for maintenance and growth, and those derived from nutritionally incomplete diets, are metabolized, resulting in $\mathrm{NH}_{3}-\mathrm{N}$ excretion (Lehninger, Nelson \& Cox 1993; Rosas et al. 1996). Based on Hewitt \& Irving (1990) and Rosas et al. (1996), Montoya and colleagues (Montoya et al. 1999) assumed in their model that shrimp excrete any nitrogen in excess of that needed for growth as EMBED (NEA). This $\mathrm{NH}_{3}-\mathrm{N}(\mathrm{mg})$ with water establishes an equilibrium with $\mathrm{NH}_{4}{ }^{+}-\mathrm{N}$. The amount of $\mathrm{NH}_{3}-\mathrm{N}(\mathrm{mg})$ in the form of $\mathrm{NH}_{4}{ }^{+}-\mathrm{N}(\mathrm{am})$ is determined by the constant ammonium proportion (AP, 95\%, Bower \& Bidwell $1978)$ at the constant $\mathrm{pH}(7.8-8.0)$ and temperature $\left(28-30^{\circ} \mathrm{C}\right)$ assumed in this model, as show in equation 1 :

$$
\mathrm{am}=\mathrm{NEA} \times \mathrm{AP}
$$

A proportion of $\mathrm{NH}_{4}{ }^{+}-\mathrm{N}$ is taken up by heterotrophic bacteria $(\mathrm{hu})$ and the remainder is converted to $\mathrm{NO}_{2}{ }^{-} \mathrm{N}$ (ns). Although phytoplankton is thought to be responsible for most of the inorganic nitrogen uptake, recent evidence suggests that heterotrophic 


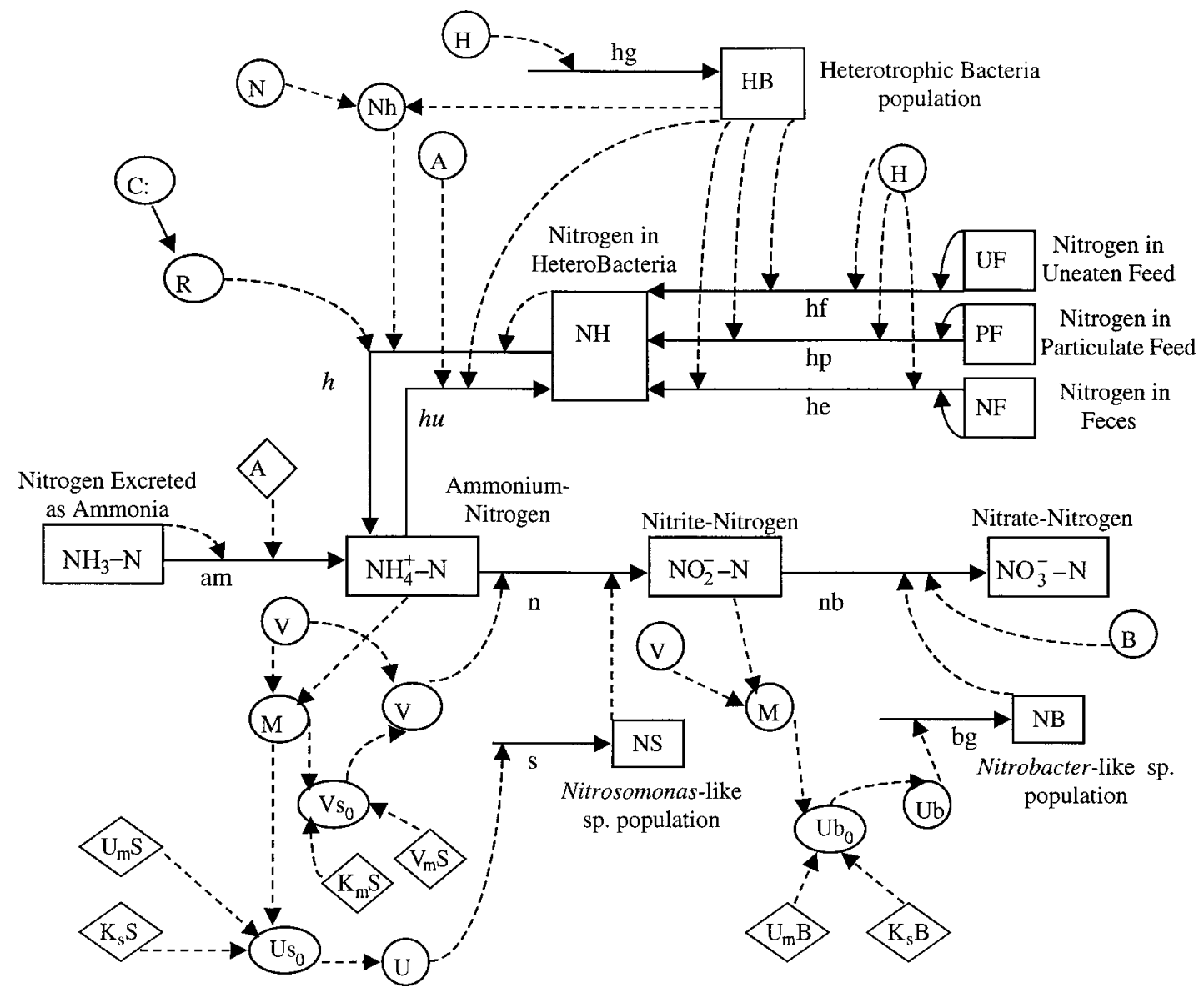

Figure 1 Conceptual model representing bacterially mediated processes in an intensive shrimp culture system. State variables are denoted by three large upper-case letters and are represented by boxes. Driving variables are denoted by two upper-case letters and are represented by circles. Constants are denoted by two upper-case letters and are represented by diamond shapes. Auxiliary variables are denoted by an upper-case letter followed by a lower-case letter and are represented by circles. Material transfers are denoted by two lower-case letters and are represented by solid arrows. Information transfers are represented by dotted arrows. Abbreviations are defined in the text.

Figure 2 Conceptual model representing shrimp mortality in an intensive shrimp culture system. Symbols are defined as in Fig. 1 and abbreviations are defined in the text.

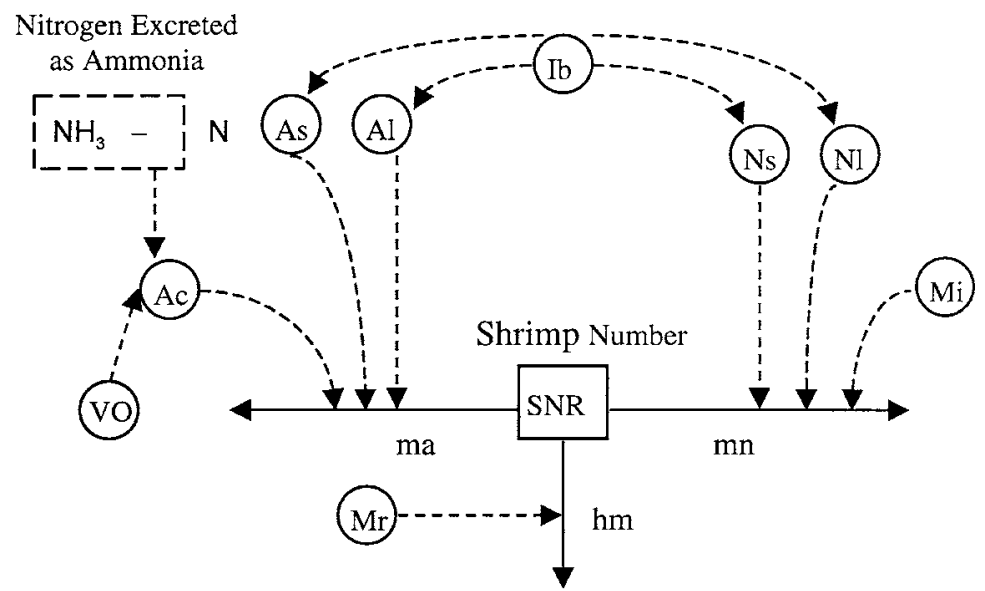


bacteria may play a significant role in the utilization of inorganic nitrogen and may compete successfully with phytoplankton for uptake of $\mathrm{NH}_{4}{ }^{+}-\mathrm{N}$ (Goldman, Caron, Andersen \& Dennett 1985; Wheeler \& Kirchman 1986; Fuhrman et al. 1988). Thus, the present model includes the bacterial role with respect to inorganic nitrogen use. The amount of $\mathrm{NH}_{4}{ }^{+}-\mathrm{N}$ used by heterotrophic bacteria $(\mathrm{hu})$ is calculated based on the $\mathrm{NH}_{4}{ }^{+}-\mathrm{N}$ uptake rate $(\mathrm{AH}$, $8.0 \times 10^{-13} \mathrm{mg} \mathrm{N}$ cell $^{-1} \mathrm{~h}-1$; Wheeler \& Kirchman 1986) and the heterotrophic bacterial population (HBP), as show in equation 2 :

$$
\mathrm{hu}=\mathrm{NH}_{4}{ }^{+}-\mathrm{N} \times \mathrm{AH} \times \mathrm{HBP}
$$

HBP is represented as number of cells and its net growth (hg) is a function of growth rate (HG, $0.025 \mathrm{~h}^{-1}$; Wheeler \& Kirchman 1986), as show in equation 3 :

$$
\text { hg }=\mathrm{HBP} \times \mathrm{HG}
$$

However, heterotrophic bacterial production and bacterial nitrogen demand determined in estuarine and coastal ecosystems appear to be higher than maximum $\mathrm{NH}_{4}{ }^{+}$uptake rates, indicating that bacteria may use other organic nitrogen compounds, such as free amino acids and dissolved proteins (Wheeler \& Kirchman 1986; Fuhrman et al. 1988). Heterotrophic bacteria in aquaculture systems may use nitrogen in uneaten whole feed, feed disintegrate in particles and faeces, which hereafter will be referred to as nitrogen in detritus. The use of nitrogen in detritus by heterobacteria (hf, hp, he) is determined by detritus uptake rate (HD, $1 \times 10^{-8} \%$ cell $^{-1} \mathrm{~h}^{-1}$; Holliaugh \& Azam 1983), amount of available detritus (UFN, PFN, NFE) and the heterotrophic bacterial population (HBP). The detritus uptake is represented as a percentage of nitrogen in detritus used per cell as show in equations 4,5 and 6. It is assumed there is no preferential usage of substrate by heterobacteria.

$$
\begin{aligned}
& \mathrm{hf}=\mathrm{UFN} \times \mathrm{HD} \times \mathrm{HBP} \\
& \mathrm{hp}=\mathrm{PFN} \times \mathrm{HD} \times \mathrm{HBP} \\
& \mathrm{he}=\mathrm{NFE} \times \mathrm{HD} \times \mathrm{HBP}
\end{aligned}
$$

Until recently, it was believed that bacteria were primarily nitrogen regenerators, however, new studies indicate that direct excretion of inorganic nutrients during active growth of bacteria is not a major mode of remineralization (Azam, Fenchel, Field, Gray, Meyer-Reil \& Thingstad 1983; Goldman, Caron, Andersen \& Dennett 1985). Two criteria must be met for bacteria in the exponential growth phase to regenerate nutrients: first, nitrogen must come from an organic substrate; and second the C:N ratio of the bacterial biomass must be greater than the C:N ratio of the available substrate (Goldman, Caron \& Dennett 1987). Goldman and colleagues (Goldman et al. 1987) found that the C:N ratio of organic substrate affects bacterial gross growth efficiencies and regeneration, while bacteria $\mathrm{C}: \mathrm{N}$ was very similar regardless of $\mathrm{C}: \mathrm{N}$ of substrate. They also found no net regeneration during the bacterial exponential growth phase when $\mathrm{NH}_{4}{ }^{+}$was the only source of nitrogen. Regeneration of $\mathrm{NH}_{4}{ }^{+}$during the exponential growth phase increases with decreasing $\mathrm{C}: \mathrm{N}$ ratio, whereas during the stationary phase, $\mathrm{NH}_{4}{ }^{+}$excretion increased with increasing $\mathrm{C}: \mathrm{N}$ ratio of the initial substrate and occurred concomitantly with losses in particulate nitrogen. In the model, the amount of $\mathrm{NH}_{4}{ }^{+}-\mathrm{N}$ regenerated by heterobacteria $(\mathrm{hr})$ is a function of the nitrogen accumulated in the heterotrophic bacterial population (NHB) and the regeneration rate ( $\mathrm{Rr})$. Regeneration rate is a function of $\mathrm{C}: \mathrm{N}$ ratio $(\mathrm{C}: \mathrm{N})$ and is calculated by fitting the regeneration results of Goldman et al. (1987) for the exponential and stationary phase vs. C:N ratios in a polynomial curve as follows:

$$
\begin{gathered}
\text { Regeneration rate }(\%)=88.0-7.0(\mathrm{C}: \mathrm{N} \text { ratio }) \\
+0.12(\mathrm{C}: \mathrm{N} \text { ratio })^{2}\left(\mathrm{r}^{2}=0.98, \mathrm{n}=6\right)
\end{gathered}
$$

The C:N ratio of the feed is defined by the user for each simulation. It is assumed that this $\mathrm{C}: \mathrm{N}$ ratio is maintained in detritus. In addition, regeneration occurs only when nitrogen comes from detritus and is above the minimum nitrogen content $(\mathrm{Nh})$ of the heterotrophic bacterial population (HBP). The minimum nitrogen content of heterotrophs $(\mathrm{Nh})$ is determined by the heterotrophic population (HBP) multiplied by the nitrogen content per cell (NC, $6 \times 10-12 \mathrm{mg} \mathrm{N}$ cell $^{-1}$, Fuhrman et al. 1988) as shown in equation 7 :

$$
\begin{gathered}
\text { if } \mathrm{NHB}<\mathrm{Nh} \text { or UFN, PFN or NFE }=0 \text { then, } \mathrm{h}=0 \\
\text { if } \mathrm{NHB}>\mathrm{Nh} \text { and } \mathrm{UFN}, \mathrm{PFN} \text { or NFE }>0 \\
\text { then, } \mathrm{h}=\mathrm{NHB} \times \mathrm{Rr}
\end{gathered}
$$


Ammonia excreted by shrimp and produced by heterobacteria may be used by nitrifying bacteria to obtain energy for growth by oxidizing ammonia to nitrate (Fry 1987). Nitrifying bacteria can play an important role in the turnover of nitrogen in marine environments (Helder \& DeVries 1983). Heterotrophic nitrification is thought to be insignificant in aquatic habitats and, therefore, the important nitrifiers in water are the autotrophic nitrifiers or Nitrobacteriacea, which include two groups of bacteria that use different respiratory mechanisms in two consecutive steps. First, $\mathrm{NH}_{4}{ }^{+}$oxidation $\mathrm{NO}_{2}{ }^{-}$ is executed by strictly chemolithotrophic aerobic bacteria such as Nitrosomonas sp. and Nitrosococcus sp. Second, the oxidation of $\mathrm{NO}_{2}{ }^{-}$to $\mathrm{NO}_{3}{ }^{-}$is performed by facultative chemolithotrophic bacteria such as Nitrobacter sp. (Vymazal 1994).

Information about nitrification in aquaculture systems is rare and limited to biofilters. Few measurements of the actual rates of nitrification have been reported from coastal and estuarine waters and results vary widely (Iriarte, Madariaga, Diez-Garagarza, Revilla \& Orive 1996). In addition to the wide variation, few studies present the two nitrification steps separately, making it very hard to estimate the intermediate product, nitrite. Ward (1982) reported the kinetics of ammonia oxidation by Nitrosococcus oceanus, indicating that oxidation rate increased with increasing substrate concentration following a Michaelis-Menten hyperbolic curve. It is assumed that Nitrosomonas sp. oxidated $\mathrm{NH}_{4}{ }^{+}-\mathrm{N}$ at a similar rate to Nitrosococcus oceanus. In the model, the amount of $\mathrm{NH}_{4}{ }^{+}-\mathrm{N}$ transformed to $\mathrm{NO}_{2}{ }^{-} \mathrm{N}$ (ns) depends on the velocity of the $\mathrm{NH}_{4}{ }^{+}-\mathrm{N}$ oxidation reaction (Vs) and the Nitrosomonas-like sp. population (NSP), as show in equation 8 :

$$
\mathrm{ns}=\mathrm{Vs} \times \mathrm{NSP}
$$

The velocity of $\mathrm{NH}_{4}{ }^{+}-\mathrm{N}$ oxidation reaction (Vs) is represented as amount of $\mathrm{NH}_{4}{ }^{+}-\mathrm{N}$ in mg transformed to $\mathrm{NO}_{2}{ }^{-} \mathrm{N}$ per cell of Nitrosomonas-like sp. The velocity of $\mathrm{NO}_{2}^{-}-\mathrm{N}$ oxidation (Vs) is an auxiliary variable used to determine the inverse of the initial velocity $\left(\mathrm{Vs}_{0}\right)$ and transform units from $\mu \mathrm{mol}$ $\mathrm{NH}_{4}{ }^{+}-\mathrm{N} \mathrm{L}^{-1}$ cell $^{-1} \mathrm{~h}^{-1}$ to $\mathrm{mg} \mathrm{N}$ cell ${ }^{-1} \mathrm{~h}^{-1}$. The initial velocity $\left(\mathrm{Vs}_{0}\right)$ is calculated based on the LineweaverBurk equation described by Ward (1982) for Nitrosoccocus oceanus, as show in equation 9:

$$
\frac{1}{\mathrm{VS}_{0}}=\frac{\mathrm{K}_{\mathrm{m}} \mathrm{S}}{\mathrm{V}_{\mathrm{m}} \mathrm{S}} \times\left(\frac{1}{\mathrm{Mu}}\right)+\left(\frac{1}{\mathrm{~V}_{\mathrm{m}} \mathrm{S}}\right)
$$

where $\mathrm{K}_{\mathrm{m}} \mathrm{S}$ is the half-saturation constant $(200 \mu \mathrm{M})$, $\mathrm{V}_{\mathrm{m}} \mathrm{S}$ is the maximum velocity of the reaction $\left(2.2 \times 10^{-8} \mu \mathrm{molcell}{ }^{-1} \mathrm{~h}^{-1}\right)$, and $\mathrm{Mu}$ is $\mathrm{NH}_{4}{ }^{+} \mathrm{N}$ concentration in $\mu \mathrm{M}$, which depends on water volume (VO) and total $\mathrm{NH}_{4}{ }^{+}-\mathrm{N}$ in the system.

Because nitrification is carried out by microbes, the rate of nitrification is directly proportional to the growth of nitrifying bacteria (Kadlec \& Knight 1996). The Monod expression provides a convenient relationship for predicting bacterial growth rate (U) based on concentration of a limiting substrate (S), the maximum potential growth rate when that substrate is not limiting $\left(\mathrm{U}_{\mathrm{m}}\right)$, and the half-saturation constant $\mathrm{K}_{\mathrm{s}}$ for that substrate (Kadlec \& Knight 1996). The Nitrosomonas-like sp. population (NSP) is represented as number of cells. Net growth (sg) of the Nitrosomonas-like sp. population is a function of the growth rate $\left(\mathrm{U}_{\mathrm{s}}\right)$, which is the inverse of the specific growth rate $\left(\mathrm{Us}_{0}\right)$ calculated based on the linear equation of the Monod expression described by Helder \& DeVries (1983) for Nitrosomonas-like sp., as show in equation 10:

$$
\frac{1}{\mathrm{Us}_{0}}=\left(\frac{\mathrm{K}_{\mathrm{s}} \mathrm{S}}{\mathrm{U}_{\mathrm{m}} \mathrm{S}}\right) \times\left(\frac{1}{[\mathrm{~S}]}\right)+\left(\frac{1}{\mathrm{U}_{\mathrm{m}} \mathrm{S}}\right)
$$

where $\mathrm{K}_{\mathrm{s}} \mathrm{S}$ is the half-saturation constant $\left(55.4 \mu \mathrm{mol} \mathrm{L}^{-1}\right), \mathrm{UmS}$ is the maximum growth rate $\left(0.036 \mathrm{~h}^{-1}\right)$, and $[\mathrm{S}]$ is $\mathrm{NH}_{4}{ }^{+}-\mathrm{N}$ concentration $(\mathrm{Mu})$ in $\mu \mathrm{M}$.

The $\mathrm{NH}_{4}{ }^{+}-\mathrm{N}$ transformed to $\mathrm{NO}_{2}{ }^{-}-\mathrm{N}$ subsequently is transformed to $\mathrm{NO}_{3}{ }^{-} \mathrm{N}(\mathrm{nb})$ as a function of oxidation rate $\left(\mathrm{BR}, 2.2 \times 10^{-10} \mathrm{mg} \mathrm{N}\right.$ cell $^{-1} \mathrm{~h}^{-1}$, Bianchi, Bonin \& Feliatra 1994) and the Nitrobacterlike sp. population (NBP) as show in equation 11. Nitrobacter-like sp. population is represented as number of cells.

$$
\mathrm{nb}=\mathrm{NO}_{2}^{-}-\mathrm{N} \times \mathrm{BR} \times \mathrm{NBP}
$$

where Net growth (bg) of Nitrobacter-like sp. is a function of the growth rate (Ub), which is the inverse of the specific growth rate $\left(\mathrm{Ub}_{0}\right)$ determined using the Monod equation and the constants reported by Helder \& DeVries (1983) for Nitrobacter sp., including the half-saturation constant $\left(\mathrm{K}_{\mathrm{s}} \mathrm{B}\right.$, $\left.267.2 \mu \mathrm{mol} \mathrm{L}^{-1}\right)$ and maximum growth rate $\left(\mathrm{U}_{\mathrm{m}} \mathrm{B}\right.$, $\left.0.064 \mathrm{~h}^{-1}\right)$.

In this case, [S] represents $\mathrm{NO}_{2}{ }^{-}-\mathrm{N}$ concentration (Mi), which, in turn, is a function of water volume (VO) in the culture system and total $\mathrm{NO}_{2}{ }^{-} \mathrm{N}$ in the culture system. 


\section{Survival submodel}

This submodel represents shrimp survival (Fig. 2) as a function of (i) site-specific mortality; (ii) median mortality as a result of acute toxicity of $\mathrm{NH}_{3}-\mathrm{N}$; and (iii) median mortality as a result of acute toxicity of $\mathrm{NO}_{2}{ }^{-}-\mathrm{N} . \mathrm{NH}_{3}-\mathrm{N}$ and $\mathrm{NO}_{2}{ }^{-}-\mathrm{N}$ concentrations are controlled by the bacteria-mediated processes submodel. Mortality as a result of low oxygen concentration or temperature is not considered in this submodel because these parameters are represented as constants within the optimum ranges for the species.

Shrimp number is represented as a single state variable (SNR), and the initial value is the number of stocked animals selected by the user within the range for intensive systems (above 25 animals per $\mathrm{m}^{-2}$; A. L. Lawrence, personal communication). Site-specific mortality (hm) is a function of mortality rate $(\mathrm{Mr})$ specified by the model user, based on records from commercial operations as an average daily percentage of animals dying because of condition of the animals, stress during acclimation and stocking, or epizootics, as show in equation 12 :

$$
\mathrm{hm}=\mathrm{SNR} * \mathrm{Mr}
$$

$\mathrm{NH}_{3}$ is considered to be the most toxic form because it has high lipid solubility and is able to diffuse through the cell membranes (Fromm \& Gillette 1968). $\mathrm{NH}_{3}$ toxicity may be acute or chronic. Most studies refer to acute toxicity and use static bioassay tests, under controlled conditions, evaluating one or two variables. Results from these studies are usually reported as median lethal concentration, $\mathrm{LC}_{50}$, meaning the concentration required to kill 50\% of the population at a reported exposure time and specific environmental conditions. Most studies have been conducted with other species and information on L. vannamei is limited. In the submodel, the median mortality as a result of acute toxicity of $\mathrm{NH}_{3}-\mathrm{N}$ (ma) occurs when $\mathrm{NH}_{3}-\mathrm{N}$ concentration (Ac, $\mathrm{mg} \mathrm{NL}^{-1}$ ) is equal or higher than the median lethal $\mathrm{NH}_{3}-\mathrm{N}$ concentration, which is specific for small (As) or large animals (Al). Animals are considered small when individual shrimp biomass (Ib) is below or equal to $0.27 \mathrm{~g}$, and large when it is above $0.27 \mathrm{~g}$. The user forecasts changes in daily individual shrimp biomass ( $\mathrm{Ib}$ ) according to previous experience. $\mathrm{NH}_{3}-\mathrm{N}$ concentration (Ac) is a function of total $\mathrm{NH}_{3}-\mathrm{N}$ in the system (mg N) from the previous submodel and water volume (VO, L, user decision).
Median lethal $\mathrm{NH}_{3}-\mathrm{N}$ for small animals (As) was determined by fitting the data of Jiang, Grant \& Lawrence (1999) for L. vannamei in a logarithmic regression as show in equation 13 :

$$
\begin{aligned}
\operatorname{As}\left(\mathrm{mg} \mathrm{N} \mathrm{L}^{-1}\right)= & 5.83-1.99 * \log (\text { hours }) \\
& \left(r^{2}=0.97, n=5\right)
\end{aligned}
$$

and for large animals (Al) by fitting the data of Chen \& Lei (1990) for Penaeus monodon in a logarithmic regression as show in equation 14 :

$$
\begin{aligned}
\mathrm{Al}\left(\mathrm{mg} \mathrm{N} \mathrm{L}^{-1}\right)= & 5.38-2.05 * \log (\text { hours }) \\
& \left(r^{2}=0.96, n=8\right)
\end{aligned}
$$

Median mortality as a result of acute toxicity of $\mathrm{NO}_{2}{ }^{-}-\mathrm{N}(\mathrm{mn})$ occurs when $\mathrm{NO}_{2}{ }^{-}-\mathrm{N}$ concentration (Mi) is equal to or higher than the median lethal $\mathrm{NO}_{2}{ }^{-} \mathrm{N}$ concentration, which is specific for small (Ns) or large animals (Nl). Median lethal $\mathrm{NO}_{2}{ }^{-} \mathrm{N}$ concentration for small animals (Ns) was determined by fitting the data of Chen \& Chin (1988) for $P$. monodon in a logarithmic equation as follows:

$$
\begin{gathered}
\mathrm{Ns}\left(\mathrm{mg} \mathrm{L}^{-1}\right)=172.46-8.13 * \log (\text { hours }) \\
\left(r^{2}=0.99, n=4\right)
\end{gathered}
$$

and for large animals by fitting the data of Chen \& Lei (1990) for P. monodon in a logarithmic regression as show in equation 16 :

$$
\begin{aligned}
\mathrm{Nl}\left(\mathrm{mg} \mathrm{L}^{-1}\right)= & 472.6-200.18 * \log (\text { hours }) \\
& \left(r^{2}=0.92, n=8\right)
\end{aligned}
$$

\section{Model evaluation}

Nitrogen nitrification and heterotrophic bacteria use and regeneration of $\mathrm{NH}_{4}{ }^{+}-\mathrm{N}$ have not been evaluated in shrimp culture systems and information for evaluation is limited. Most of the information was obtained from natural ecosystems, which mainly differ with aquaculture systems in the lack of a constant fairly high input of nutrients in the form of artificial feed. However, a preliminary evaluation was conducted to determine which research items need to be investigated.

Evaluation of this model consisted of simulating two indoor experiments conducted at the Shrimp Mariculture Research Laboratory, Texas A \& M University System, and one outdoor experiment conducted at The Oceanic Institute, Hawaii. These 
experiments examined the effect of dietary protein level in semi-purified diets (expt 1), feeding frequency (expt 2), and dietary protein level in commercial diets (expt 3) on concentrations of total ammonia-nitrogen (TAN), nitrite-nitrogen (NIC), nitrate-nitrogen (NAC) and total inorganic nitrogen (TIN) in the water. Nitrogen excreted as ammonia (NEA), and nitrogen in particulate feed (PFN), uneaten feed (UFN), and faeces (NFE) were determined for each experiment using the simulation model developed by Montoya et al. (1999). Carbon: nitrogen ratio $(\mathrm{C}: \mathrm{N})$ of diets was determined assuming that most carbohydrates were in the form of starch.

A modified two-sample $t$-test (Steel \& Torrie 1988) at the $95 \%$ confidence level was used to compare simulated and experimental TAN, NIC, NAC and TIN concentrations in the water, and shrimp survival. Simulated parameters in p.p.m. (or $\mathrm{mg} \mathrm{L}^{-1}$ ) were calculated as follows:

$$
\begin{gathered}
\mathrm{TAN}=\frac{\mathrm{NH}_{4}^{+}-\mathrm{N}+\mathrm{NH}_{3}-\mathrm{N}}{\mathrm{VO}} \\
\mathrm{NIC}=\frac{\mathrm{NO}_{2}^{-}-\mathrm{N}}{\mathrm{VO}} \\
\mathrm{NAC}=\frac{\mathrm{NO}_{3}^{-}-\mathrm{N}}{\mathrm{VO}} \\
\mathrm{TIN}=\frac{\mathrm{NEA}+\mathrm{NH}_{4}^{-}-\mathrm{N}+\mathrm{NO}_{2}^{-}-\mathrm{N}+\mathrm{NO}_{3}^{-}-\mathrm{N}}{\mathrm{VO}}
\end{gathered}
$$

where, VO is the water volume of the culture system in litres.

Because information about bacterial populations from experiments or any other aquaculture system was not available, populations of heterotrophic bacteria (HBPi), Nitrosomonas-like sp. (NSPi), and Nitrobacter-like sp. (NBPi) were adjusted initially using the model. Simulated heterotrophic bacteria (HBP), Nitrosomonas-like sp. (NSP), and Nitrobacterlike sp. (NBP) populations were monitored to assure that they did not exceed theoretical limits. Final bacterial populations were divided by VO to determine population densities. The theoretical maximum bacterial population density found in artificial culture systems is approximately $1 \times 10^{11} \mathrm{cell} \mathrm{L}^{-1}$ (Douillet, personal communication). Comparisons of simulated and actual experiments are summarized below. The simulation period for both indoor expts 1 and 2 was $480 \mathrm{~h}$ (20 days) and for the outdoor expt 3, 2016 hours (12 weeks).

\section{Experiment 1: effect of protein levels of semi-purified diets}

Experiment 1 examined the effect of four dietary protein levels $(11 \%, 19 \%, 25 \%$ and $33 \%)$ on TAN, NIC, NAC and TIN concentrations in the water, and on shrimp survival (Velasco 1996). Carbon:nitrogen ratios $(\mathrm{C}: \mathrm{N})$ were $15.51,7.33,5.05$ and 3.18 respectively. Each treatment had six replicates. Initial shrimp number (SNRi) was 30 animals per tank and tank volume (VO) was $20 \mathrm{~L}$. The amount of nitrogen excreted by the animals (NEA) and available detritus (UFN, PFN, NFE) are presented in Fig. 3.

Initial heterotrophic bacterial populations were similar for $19 \%, 26 \%$ and $33 \%$ protein levels, but was lower at $11 \%$ protein (Table 1a). Initial Nitrosomonas sp. populations decreased with increasing protein levels (Table 1a). Initial Nitrobacter sp. populations were similar for $11 \%, 19 \%$, and $26 \%$ protein levels, but was higher at $33 \%$ protein (Table 1a).

There were no statistically significant differences between simulated and experimentally observed TAN, NCI, NAC and TIN concentrations, nor between simulated and experimentally observed shrimp survival $(\%)(P>0.05)$. TIN increased with increases in dietary protein level, as reported by Velasco (1996) (Table 2a). Final bacteria populations did not exceed theoretical limits (Table 1a).

\section{Experiment 2: effect of feeding frequency of semi-purified diets}

Experiment 2 examined the effect of four feeding frequencies (3, 5, 8 and 15 times per day) on TAN, NIC, NAC, and TIN concentrations in the water, and on shrimp survival (Velasco, Lawrence \& Castille 1999). Carbon:nitrogen ratio (C:N) was 7.33. Each treatment had seven replicates. Initial shrimp number (SNRi) was 30 animals per tank and tank volume (VO) was $20 \mathrm{~L}$. The amount of nitrogen excreted by the animals (NEA) and amount of available detritus (UFN, PFN, NFE) are presented in Fig. 4.

Initial heterotrophic bacteria populations were increased with increasing feeding frequency. Initial Nitrobacter sp. population were kept similar for all feeding frequencies but it was necessary to increase Nitrosomonas sp. initial values with increasing feeding frequency (Table 1b).

There were no statistically significant differences between simulated and experimentally observed TAN, NIC, NAC and TIN concentrations, nor 
(a) $11 \%$

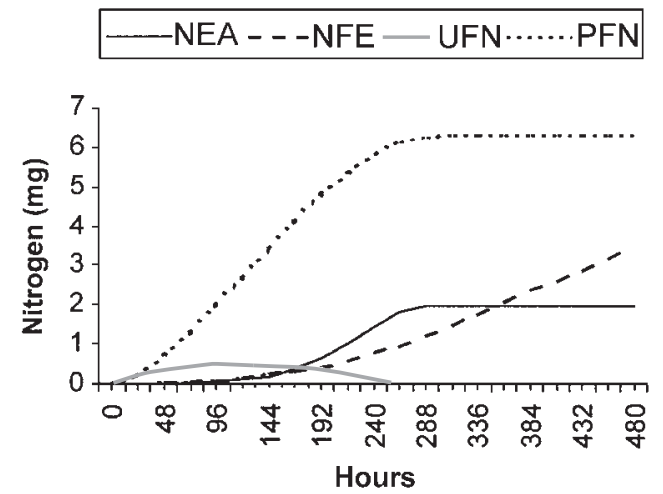

(c) $25 \%$

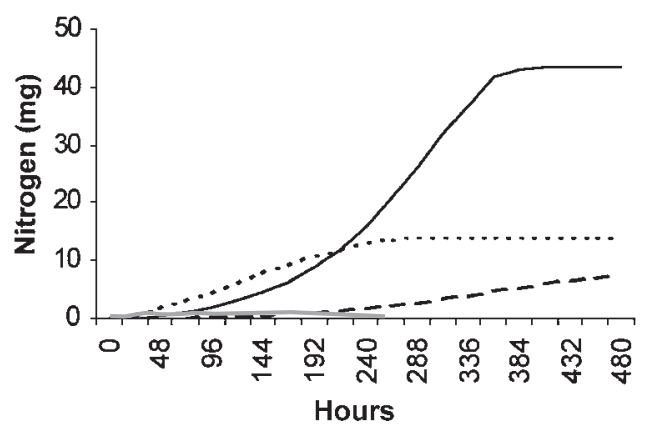

(b) $19 \%$

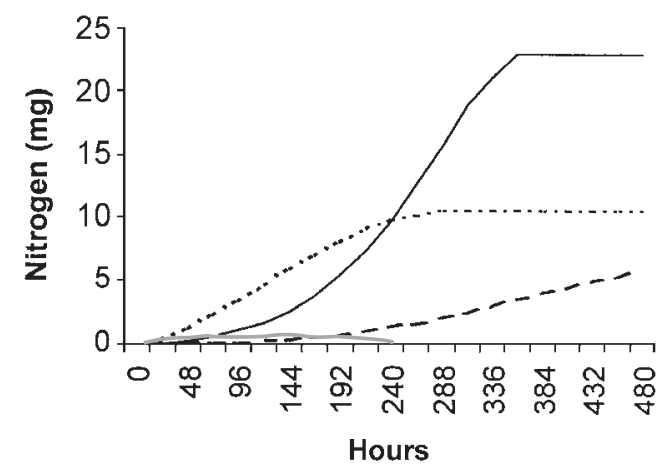

(d) $33 \%$

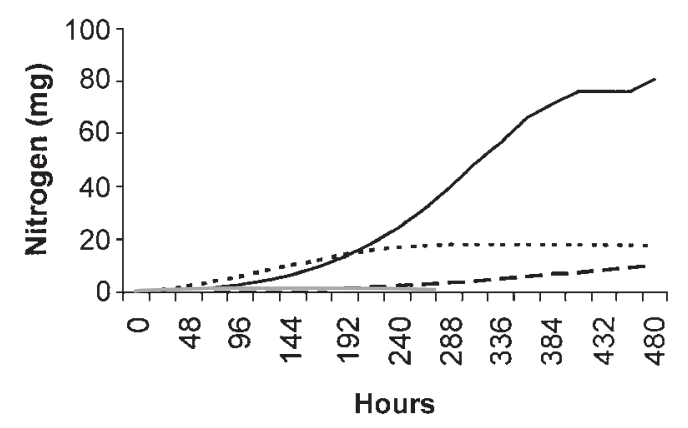

Figure 3 Nitrogen excreted (NEA), nitrogen in uneaten feed (UFN), in particulate feed (PFN) and in faeces (NFE) generated with semi-purified diets, with (a) 11\%; (b) 19\%; (c) 25\%; and (d) 33\% dietary protein (expt 1).

between simulated and experimentally observed shrimp survival $(\%)(P>0.05)$. TIN increased with increases in dietary protein level, as reported by Velasco, Lawrence \& Castille (1999) (Table 2b). Final bacteria populations did not exceed theoretical limits (Table 1b).

\section{Experiment 3: effect of protein levels of commercial diets}

Experiment 3 examined the effect of three dietary protein levels $(15 \%, 25 \%$ and $35 \%)$ on TAN, NIC, NAC and TIN concentrations in the water in outside systems that were covered to limit phytoplankton growth (The Oceanic Institute, unpublished data). Carbon:nitrogen ratios $(\mathrm{C}: \mathrm{N})$ were $7.33,5.85$ and 3.75 respectively. Each treatment had four replicates. Initial shrimp number (SNRi) was 90 animals per tank. Tank volume (VO) was $1300 \mathrm{~L}$. The amount of nitrogen excreted by the animals (NEA) and amount of available detritus (UFN, PFN, NFE) are presented in Fig. 5.
Initial heterotrophic bacterial population was similar for all protein levels (Table 1c). The initial Nitrosomonas sp. population was set at 500000 cells per tank for all treatments (Table 1c). Initial Nitrobacter sp. population was similar for $15 \%$ and $25 \%$ protein levels, but was higher at the $35 \%$ protein level (Table 1c).

There were no statistically significant differences between simulated and experimentally observed TAN, NIC, NAC and TIN concentrations, nor between simulated and experimentally observed shrimp survival $(P>0.05)$. TIN increased with increases in dietary protein level (Table 2c). Mass mortality occurred at the $35 \%$ protein level as a result of toxic ammonia and nitrite.

\section{Model sensitivity to initial size of heterotrophic bacteria populations}

It was possible to set similar initial heterotrophic populations in expts 1 and 3, except at the lowest protein level (11\%). This suggests that other factors 
Table 1 Heterotrophic bacteria (HBP), Nitrosomonas sp. (NSP) and Nitrobacter sp. (NBP) initial and final population densities obtained in the simulation of the effect of (a) dietary protein level; (b) feeding frequency; and (c) commercial feeds with three different protein levels on concentration of total inorganic nitrogen forms in the water

\begin{tabular}{|c|c|c|c|c|c|c|}
\hline \multirow{3}{*}{$\begin{array}{l}\text { Dietary protein level (\%)/ } \\
\text { feeding frequency }\end{array}$} & \multicolumn{6}{|c|}{ Bacterial population densities (number of cells $\mathrm{L}^{-1}$ ) } \\
\hline & \multicolumn{2}{|l|}{ HBP } & \multicolumn{2}{|l|}{ NSP } & \multicolumn{2}{|l|}{ NBP } \\
\hline & initial & final & initial & final & initial & final \\
\hline \multicolumn{7}{|c|}{ (a) Dietary protein level (expt 1) } \\
\hline $11 \%$ & $1 \times 10^{3}$ & $14 \times 10^{6}$ & $1 \times 10^{5}$ & $6 \times 10^{5}$ & $15 \times 10^{5}$ & $2 \times 10^{6}$ \\
\hline $19 \%$ & $2 \times 10^{5}$ & $25 \times 10^{7}$ & $2 \times 10^{3}$ & $14 \times 10^{6}$ & $1 \times 10^{6}$ & $11 \times 10^{6}$ \\
\hline $26 \%$ & $2 \times 10^{5}$ & $25 \times 10^{7}$ & $1 \times 10^{3}$ & $31 \times 10^{6}$ & $1 \times 10^{6}$ & $22 \times 10^{6}$ \\
\hline $33 \%$ & $2 \times 10^{5}$ & $25 \times 10^{7}$ & $5 \times 10^{2}$ & $41 \times 10^{6}$ & $1 \times 10^{7}$ & $25 \times 10^{6}$ \\
\hline \multicolumn{7}{|l|}{ (b) Feeding frequency (expt 2) } \\
\hline 3 times per day & $5 \times 10^{2}$ & $25 \times 10^{6}$ & $5 \times 10^{5}$ & $2 \times 10^{6}$ & $1 \times 10^{7}$ & $10 \times 10^{6}$ \\
\hline 5 times per day & $5 \times 10^{4}$ & $25 \times 10^{6}$ & $5 \times 10^{5}$ & $2 \times 10^{6}$ & $1 \times 10^{7}$ & $8 \times 10^{6}$ \\
\hline 8 times per day & $2 \times 10^{7}$ & $17 \times 10^{7}$ & $4 \times 10^{5}$ & $2 \times 10^{6}$ & $1 \times 10^{7}$ & $8 \times 10^{6}$ \\
\hline 15 times per day & $3 \times 10^{7}$ & $22 \times 10^{7}$ & $1 \times 10^{5}$ & $2 \times 10^{6}$ & $1 \times 10^{7}$ & $10 \times 10^{6}$ \\
\hline \multicolumn{7}{|l|}{ (c) Commercial feeds (expt 3) } \\
\hline $15 \%$ & $7 \times 10^{2}$ & $4 \times 10^{4}$ & $1 \times 10^{2}$ & $1 \times 10^{6}$ & $8 \times 10^{5}$ & $1 \times 10^{6}$ \\
\hline $25 \%$ & $7 \times 10^{2}$ & $4 \times 10^{4}$ & $1 \times 10^{2}$ & $7 \times 10^{6}$ & $1 \times 10^{9}$ & $2 \times 10^{9}$ \\
\hline $35 \%$ & $7 \times 10^{2}$ & $4 \times 10^{4}$ & $1 \times 10^{2}$ & $14 \times 10^{6}$ & $2 \times 10^{9}$ & $3 \times 10^{9}$ \\
\hline
\end{tabular}

affect bacterial growth under these limiting nutrient conditions. In expt 2, it was necessary to increase initial heterotrophic populations with increasing feeding frequencies. This again suggests that factors other than the amount of nitrogen available affect growth rate.

It was possible to set similar initial Nitrosomonas sp. populations in expts 1 and 3, except at the lowest protein level $(11 \%)$, when it was necessary to increase it. The specific growth rate equation used was determined in a temperate system, the Ems-Dollard estuary, The Netherlands, which has different ecological characteristics from a tropical eutrophic aquaculture system. In expt 2 , it was necessary to decrease Nitrosomonas sp. initial populations with increasing feeding frequencies (Table $1 \mathrm{~b}$ ), perhaps because the specific growth rate equation does not take into account factors other than substrate concentration that could be affecting growth (e.g. surface area). The increase of the initial Nitrobacter sp. bacterial population were increasing protein levels in expts 1 and 3, may be because the model does not include a nitrite oxidation equation that responds to substrate concentrations.

\section{Model sensitivity to detritus degradation rates}

To identify the range of degradation rates that predicts reasonable TIN values, four series of 20-day simulations at dietary protein levels of $11 \%, 19 \%$, $26 \%$ and $33 \%$ were evaluated. Each series consisted of four simulations in which degradation rate was set at $0.5,1.0,1.5$ and 2 times its baseline value respectively. All other parameters were set as in expt 1. During each simulation TIN was monitored.

Increasing or decreasing degradation rate did not affect TIN values (Table 3) at any of the dietary protein levels under the scenario described. This suggests that the degradation rate used in the baseline simulation is an adequate representation of the culture system considered herein.

In summary, the model seems capable of predicting total ammonia nitrogen (TAN), nitrite nitrogen (NIC), nitrate nitrogen (NAC) and total inorganic nitrogen (TIN) concentrations in the water under a variety of dietary protein levels and feeding frequencies once initial bacterial populations have been identified. Also, the model adequately represents site-specific mortality and mortality as a result of 


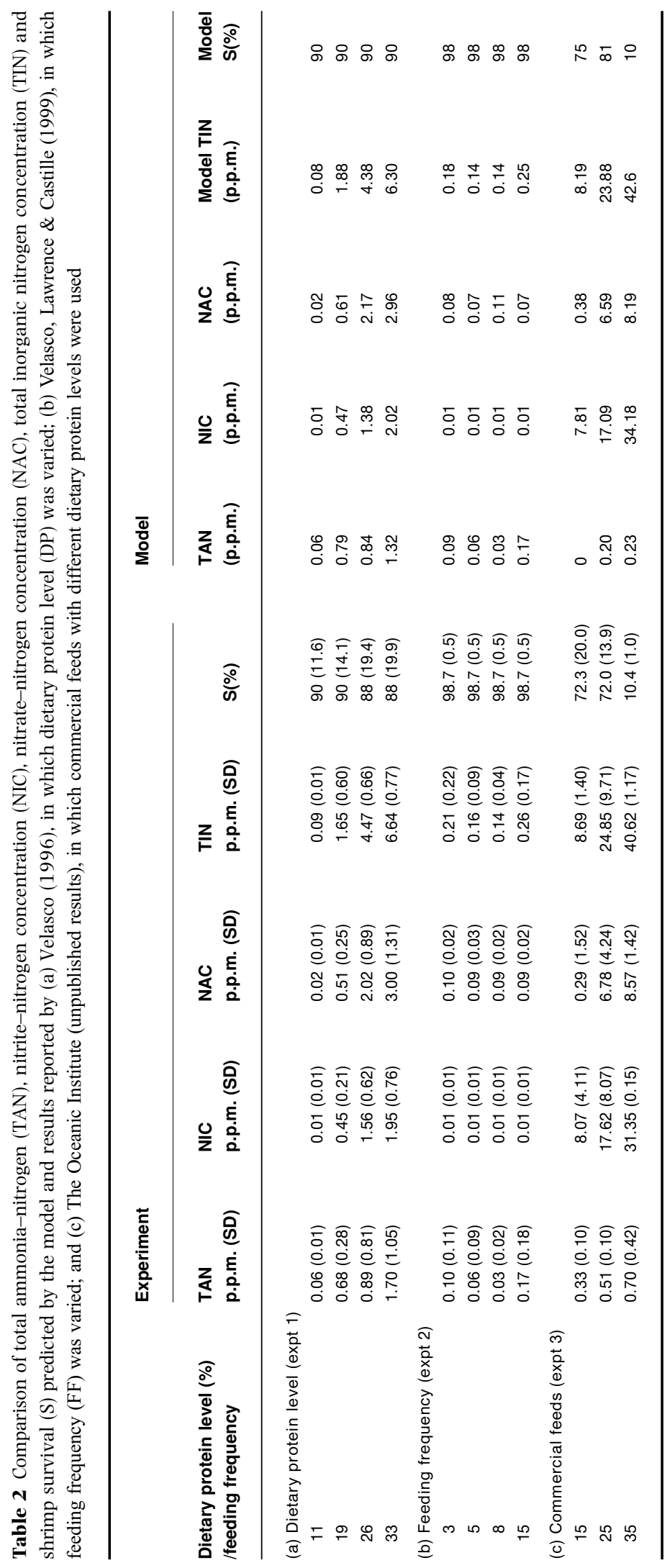


(a) 3 times

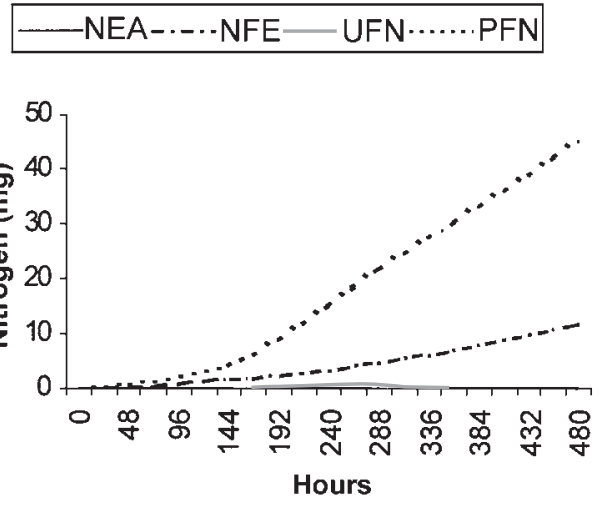

(c) 8 times

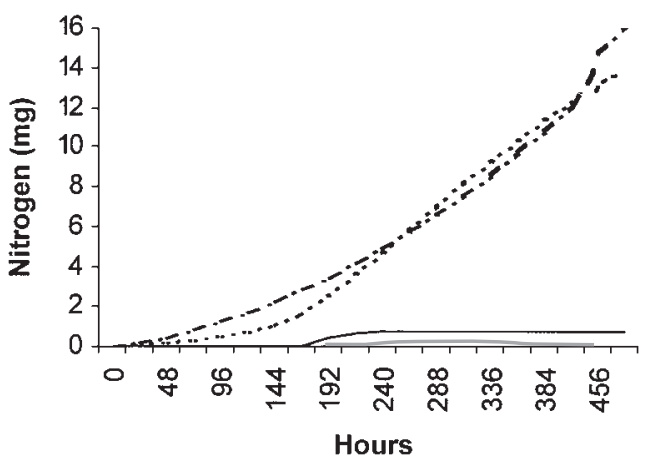

(b) 5 times

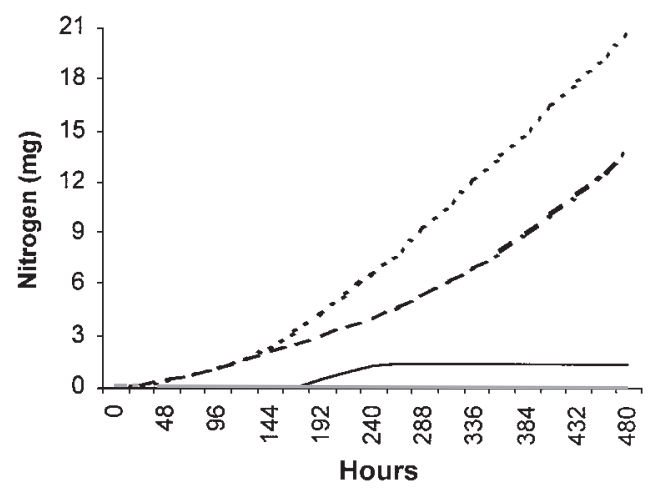

(d) 15 times

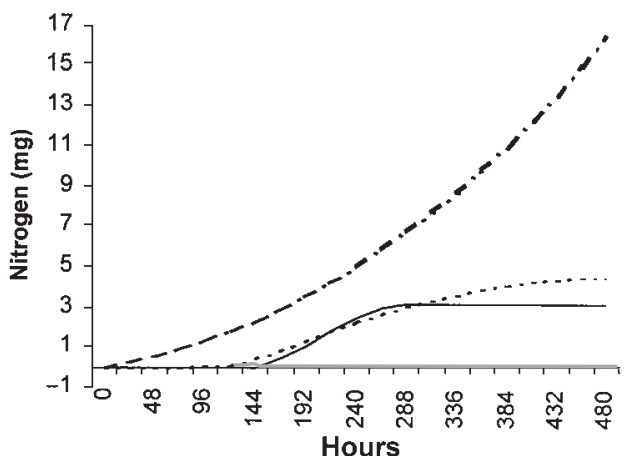

Figure 4 Nitrogen excreted (NEA), nitrogen in uneaten feed (UFN), nitrogen in particulate feed (PFN), and nitrogen in faeces (NFE) generated with daily feeding frequencies of (a) three times; (b) five times; (c) eight times; and (d) fifteen times (expt 2).

toxic ammonia and nitrite. Although bacteria dynamics are complex, these results suggest that it is possible to predict inorganic nitrogen dynamics. Thus, the effort required to determine degradation and nitrification rates in aquaculture systems appears justified, given the possibility to simulate the effect of different feeding strategies on water quality parameters critical for shrimp growth and survival.

\section{Simulation of effect of ammonium regeneration by heterotrophs on TIN}

Increasing protein level and/or feeding rates are common practices in commercial operations to increase production. We used the model to examine the effect of bacterial $\mathrm{NH}_{4}{ }^{+}-\mathrm{N}$ regeneration under the scenario described in expt 3. Three series of
Table 3 Effect of heterotrophic degradation rate (HD) variations on total inorganic nitrogen concentration (TIN) in the water at different dietary protein (DP) levels

\begin{tabular}{|c|c|c|c|c|}
\hline \multirow[b]{2}{*}{ Dietary protein (\%) } & \multicolumn{4}{|c|}{ TIN (p.p.m.) } \\
\hline & $0.5 \mathrm{HD}$ & $1 \mathrm{HD}$ & $1.5 \mathrm{HD}$ & $2 \mathrm{HD}$ \\
\hline 11 & 0.07 & 0.07 & 0.07 & 0.07 \\
\hline 19 & 1.88 & 1.88 & 1.88 & 1.88 \\
\hline 26 & 4.27 & 4.27 & 4.27 & 4.27 \\
\hline 33 & 6.51 & 6.51 & 6.51 & 6.51 \\
\hline
\end{tabular}

simulations at $15 \%, 25 \%$ and $35 \%$ protein levels were evaluated. Each series consisted of three simulations in which feeding rate was set at $0.5,1.0$, and 1.5 times the corresponding experimental value 
(a) Nitrogen in detritus at $15 \%$ protein

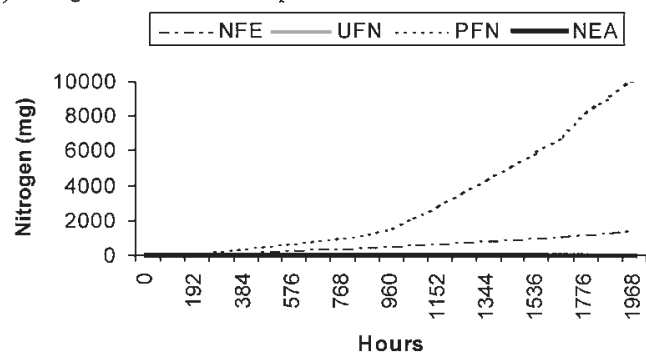

(b) Nitrogen in detritus at $25 \%$ protein

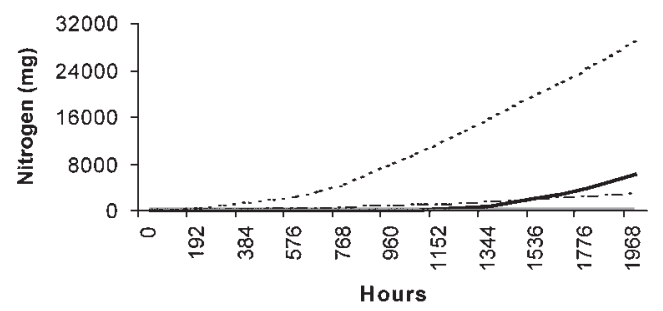

(c) Nitrogen in detritus at $35 \%$ protein

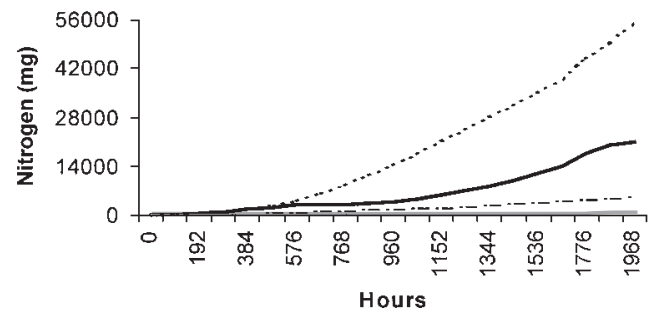

Figure 5 Nitrogen excreted (NEA), nitrogen in uneaten feed (UFN), in particulate feed (PFN), and in faeces (NFE) generated with commercial feeds, with (a) 15\%; (b) $25 \%$; and (c) 35\% dietary protein (expt 3).

respectively. During each simulation TIN, survival, and shrimp weight were monitored. To separate the effect of heterotrophic bacteria ammonium regeneration on TIN, the same series of simulations was rerun, multiplying the regeneration equation (hr) by zero. An approximate percent contribution of heterotrophic bacteria regeneration $(\mathrm{ACH})$ was calculated as follows:

$$
\mathrm{ACH}=\frac{\text { TIN with } \mathrm{hr}-\text { TIN without hr }}{\text { TIN with hr }}
$$

\section{Effect of feeding rate at $\mathbf{1 5 \%}$ dietary protein}

At $15 \%$ dietary protein, TIN values decrease with increasing feeding rate (Table $4 \mathrm{a}$ ), because shrimp use most of the extra nitrogen. Survivorship increases slightly (Table 4b) with increasing feeding rates. TIN values with and without bacteria regeneration were similar at all feeding rates, indicating that organic sources of nitrogen for bacteria are limited because shrimp use most of the nitrogen. Final shrimp weight increased as feeding rate increased (Table 4c).

\section{Effect of feeding rate at $\mathbf{2 5 \%}$ dietary protein}

At $25 \%$ dietary protein, TIN values increase with increasing feeding rate (Table 4a) whereas shrimp survival tended to decrease (Table $4 \mathrm{~b}$ ) as a result of toxic levels of ammonia. TIN values without heterotrophic bacteria regeneration were lower than corresponding values with regeneration. The contributions of heterotrophic bacteria regeneration (ACH) to TIN concentration were $40 \%, 70 \%$ and $78 \%$ at $0.5,1$, and $1.5 \mathrm{Fr}$ respectively. This indicates that more organic nitrogen was available for bacteria as feeding rates increased. ACH increased more between 0.5 and $1 \mathrm{Fr}$ than between 1 and $1.5 \mathrm{Fr}$, suggesting that shrimp excretion is more important because the animal is reaching its growth capacity and extra nitrogen beyond that needed for nitrogen accretion is excreted. Final weight increases as feeding rate increases (Table $4 \mathrm{c}$ ). Final shrimp weight increased more between 0.5 and $1 \mathrm{Fr}$ than between 1 and $1.5 \mathrm{Fr}$, suggesting that shrimp are close to their maximum growth rate under these conditions.

Table 4 (a) Total inorganic nitrogen (TIN) concentrations in the water; (b) shrimp survival; and (c) final weight of shrimp (obtained with the model of Montoya, Lawrence, Grant \& Velasco 1999), at different dietary protein (DP) levels and feeding rates, with and without heterotrophic bacteria regeneration of ammonium

\begin{tabular}{lll}
\hline $15 \% \mathrm{DP}$ & $25 \% \mathrm{DP}$ & $35 \% \mathrm{DP}$ \\
\hline
\end{tabular}

Feeding rate with without with without with without

$\begin{array}{lllllrl}\text { (a) Total inorganic nitrogen (TIN, p.p.m.) } & & \\ 0.5 & 6.48 & 6.48 & 10.25 & 6.12 & 6.05 & 0.21 \\ 1 & 6.41 & 6.41 & 23.14 & 7.05 & 41.34 & 3.26 \\ 1.5 & 6.38 & 6.38 & 42.95 & 9.27 & 72.37 & 2.26\end{array}$

(b) Shrimp survival (\%)

\begin{tabular}{lrrrrrr}
0.5 & 56 & 56 & 65 & 68 & 69 & 69 \\
1 & 61 & 61 & 64 & 70 & 11 & 12 \\
1.5 & 64 & 64 & 59 & 69 & 5 & 7 \\
(c) Final shrimp & weight $(\mathrm{g})$ & & & & \\
0.5 & 3.24 & 3.24 & 5.07 & 4.97 & 8.25 & 8.25 \\
1 & 5.60 & 5.60 & 9.50 & 9.50 & 11.66 & 11.50 \\
1.5 & 6.63 & 6.63 & 10.90 & 10.80 & 11.73 & 11.73 \\
\hline
\end{tabular}

(C) 2002 Blackwell Science Ltd, Aquaculture Research, 33, 81-94 


\section{Effect of feeding rate at $35 \%$ dietary protein}

At $35 \%$ dietary protein, TIN values increase with increasing feeding rate (Table $4 \mathrm{a}$ ), whereas survival decreased dramatically (Table 4 b) as a result of toxic levels of ammonia and nitrite. TIN values without heterotrophic bacteria regeneration were lower than corresponding values with regeneration. The contribution of heterotrophic bacteria regeneration (ACH) to TIN concentration was 90\%, 93\% and $97 \%$, at $0.5,1$, and $1.5 \mathrm{Fr}$, respectively. This indicates that bacteria regeneration is an important factor at high protein levels because the low C:N ratio of the diet stimulates regeneration, seriously affecting water quality and, therefore, survival. Similar to the results described previously, final shrimp weight increased as feeding rate increased, mainly between 0.5 and $1 \mathrm{Fr}$ (Table 4c).

These results suggest that care must be used when increasing feeding rate and protein levels to increase shrimp growth in static systems. If it is more cost-effective to increase feeding rate, a better option could be to use a low-protein diet. On the other hand, if protein level is increased, feeding rates need to be adjusted. The higher final shrimp weight obtained with high protein levels may not compensate for the higher risk of water quality problems and low survival.

\section{Conclusions}

Effects of feeding strategies and feed characteristics on total ammonia-nitrogen, nitrite-nitrogen, nitrate-nitrogen, total inorganic nitrogen and shrimp survival were closely predicted by the model, providing insight into the dynamic interactions among the diet and feeding parameters evaluated. The model was able to qualitatively follow inorganic nitrogen dynamics under conditions described. The model at its present stage may provide valuable information to manage indoor bacteria-driven culture systems and to set future research priorities. The need to manipulate initial bacterial populations points out the importance of conducting bacterial community studies and determining nitrification, degradation and regeneration rates on aquaculture systems to be able to predict inorganic nitrogen forms during the culture period. It is also very important to determine toxicity mechanisms on shrimp. Use of the model for outdoor systems is limited because of the lack of representation of plankton, some biotic components and environmental factors.

\section{Acknowledgments}

The authors wish to express thanks to Drs P. J. DuBowy and T. W. Boutton for their valuable comments. This research was funded, in part, by Project H-8158 of the Texas Agricultural Experiment Station, United States Department of Commerce Marine Shrimp Farming Program CSREES grant no. 95388081424 and no. 92388086920 , Advance Technology Program, State of Texas.

\section{References}

Azam F., Fenchel T., Field J.G., Gray J.S., Meyer-Reil L.A. \& Thingstad F. (1983) The ecological role of water-column microbes in the sea. Marine Ecology Progress Series 10, 257-263.

Bianchi M., Bonin P. \& Feliatra F. (1994) Bacterial nitrification and denitrification rates in the Rhone River plume (Northwestern Mediterranean Sea). Marine Ecology Progress Series 103, 197-202.

Bower C.E. \& Bidwell J.P. (1978) Ionization of ammonia in seawater: effects of temperature, $\mathrm{pH}$, and salinity. Journal of Fisheries Research Board of Canada 35, 1012-1016.

Chen J.C. \& Chin T.S. (1988) Acute toxicity of nitrite to tiger prawn, Penaeus monodon, larvae. Aquaculture 69. 253-262.

Chen J.C. \& Lei S.C. (1990) Toxicity of ammonia and nitrite to Penaeus monodon juveniles. Journal of the World Aquaculture Society 21, 300-306.

Fry J.C. (1987) Functional roles of the major groups of bacterial associated with detritus. In: Detritus and Microbial Ecology in Aquaculture (ed. by D.J.W. Moriarty \& R.S.V. Pullin), pp. 83-122. ICLARM, Phillipines.

Fromm P.O. \& Gillette J.R. (1968) Effect of ammonia on blood ammonia and nitrogen excretion of rainbow trout (Salmo gairdneri). Comparative Biochemistry and Physiology 26, 887-896.

Fuhrman J.A., Horrigan S.G. \& Capone D.G. (1988) Use of $13 \mathrm{~N}$ as tracer for bacterial and algal uptake of ammonium from seawater. Marine Ecology Progress Series 45 , 271-278.

Goddard S. (1996) Feed Management in Intensive Aquaculture, p. 189. Chapman \& Hall, NJ.

Goldman J.C., Caron D.A., Andersen O.K. \& Dennett M.R. (1985) Nutrient cycling in a microfagellate food chain: I. Nitrogen dynamics. Marine Ecology Progress Series 24, 231-242.

Goldman J.C., Caron D.A. \& Dennett M.R. (1987) Regulation of gross efficiency and ammonium regeneration in bacteria by substrate C:N Ratio. Limnology and Oceanography 32, 1239-1252.

Helder W. \& DeVries R.T.P. (1983) Estuarine nitrite maxima and nitrifying bacteria (Ems-Dollard Estuary). Netherlands Journal of Sea Research 17, 1-18. 
Hewitt D.R. \& Irving M.G. (1990) Oxygen consumption and ammonia excretion of the brown tiger prawn Penaeus esculentus fed diets of varying protein content. Comparative Biochemistry and Physiology 96, 373-378.

Hollibaugh J.T. \& Azam F. (1983) Microbial degradation of dissolved proteins in seawater. Limnology and Oceanography 28, 1104-1116.

Iriarte A., Madariaga I. de, Diez-Garagarza F., Revilla M. \& Orive E. (1996) Primary plankton production, respiration and nitrification in a shallow temperate estuary during summer. Journal of Experimental Marine Biology and Ecology 208, 127-151.

Jiang D., Lawrence A.L., Neill W.H., Grant W.E. \& Gong H. (1999) Lethal effect of ammonia to postlarval Penaeus vannamei at two temperatures, $25^{\circ}$ and $30^{\circ} \mathrm{C}$. In: Book of Abstracts (ed. by C.D. Webster), pp. 77. World Aquaculture Society, Tampa, FL.

Kadlec R.H. \& Knight R.L. (1996) Treatment Wetlands. CRC Press Inc, Boca Raton, FL.

Lehninger A.L., Nelson D.L. \& Cox M.M. (1993) Principles of Biochemistry. Worth Publishers, New York, NY.

Montoya R.A., Lawrence A.L., Grant W.E. \& Velasco M. (1999) Simulation of nitrogen dynamics and shrimp growth in an intensive shrimp culture system: effects of feed and feeding parameters. Ecological Modelling 122, 81-95.

Moriarty D.J.W. (1997) The role of microorganisms in aquaculture ponds. Aquaculture 151, 333-349.

Phillips M.J., Kwe-Lin C. \& Beveridge M.C.M. (1993) Shrimp culture and the environment: lessons from the world's most rapidly expanding warmwater aquaculture sector. In: Environment and Aquaculture in Developing Countries (ed. by R.S.V. Pullin, H. Rosenthal \& J.L. Maclean).
ICLARM Conference Proceedings 31, pp. 171-197. ICLARM, Philipines.

Rosas C., Sanchez A., Diaz E., Soto L.A., Gaxiola G. \& Brito R. (1996) Effect of dietary protein level on apparent heat increment and post-prandial nitrogen excretion of Penaeus setiferus, $P$. schmitti, $P$. duorarum, and P. notialis postlarvae. Journal of the World Aquaculture Society 27, 92-101.

Steele R.G.D. \& Torrie J.H. (1988) Bioestadistica: Principiosy Procedimientos. McGraw-Hill, Mexico, NM.

Velasco M. (1996) Effects of dietary protein: energy ratio and phosphorus level on growth and survival of Penaeus vannamei postlarvae and on aquacultural water quality. Doctoral Dissertation, Dep. Wildl. Fish. Sci., Texas A \& M University, College Station, Texas.

Velasco M., Lawrence A.L. \& Castille F.L. (1999) Effect of variations in daily feeding frequency and ration rize on growth of shrimp, Litopenaeus vannamei (Boone), in zero-water exchange culture tanks. Aquaculture 179 . 141-148.

Vymazal J. (1994) Algae and Element Cycling in Wetlands. Lewis Publishers. Boca Raton, FL.

Wang J. (1990) Managing shrimp pond water to reduce discharge problems. Aquacultural Engineering 9, 61-73.

Ward B.B. (1982) Oceanic distribution on ammoniaoxidizing bacteria determined by immunofluorescent assay. Journal of Marine Research 40, 1155-1172.

Wheeler P.A. \& Kirchman D.L. (1986) Utilization of inorganic and organic nitrogen by bacteria in marine systems. Limnology and Oceanography 31, 998-1009.

Wickins J.F. (1976) The tolerance of warm-water prawns to recirculating water. Aquaculture 9, 19-37. 